\title{
Investment Climate Constraints as Determinants of Political Tie Intensity in Emerging Countries: Evidence from Foreign Firms in Ghana
}

\author{
Tahiru Azaaviele Liedong ${ }^{1} \cdot$ Jedrzej George Frynas $^{2}$
}

Received: 28 October 2016 / Revised: 15 September 2017 / Accepted: 10 October 2017 / Published online: 30 May 2018

(C) The Author(s) 2018

\begin{abstract}
Foreign firms in emerging countries face various institutionally-driven challenges. Nonmarket strategy scholars argue that these challenges incite corporate political activity. Consequently, researchers have explored the influence of institutional factors on the choice and extent of political strategies. However, not much is known about how investment climate constraints affect the political ties of foreign firms in contexts other than US, Europe and Asia. Drawing on institutional theory, we propose that firms' exposure to administrative and control constraints as well as the presence of public affairs (PA) functions will lead to political tie intensification. We test our propositions using data from foreign firms operating in Ghana, and find that whereas control constraints strengthen political ties, administrative constraints weaken these ties. The findings also suggest that PA functions and political ties can be substitutes, not complements, depending on the institutional contingencies. Altogether, our study enhances knowledge and understanding of how institutional environments and organizational structures affect the political behaviour of foreign firms in emerging countries.
\end{abstract}

Keywords Political tie intensity $\cdot$ Investment climate constraints $\cdot$ Foreign firms · Emerging countries · Ghana

Tahiru Azaaviele Liedong

T.A.liedong@bath.ac.uk

1 School of Management, University of Bath, Bath, UK

2 Roehampton Business School, University of Roehampton, London, UK 


\section{Introduction}

Multinational enterprises (MNEs) in emerging countries are faced with unpredictable nonmarket environments which pose challenges to their survival and performance (Heidenreich et al. 2015; Puck et al. 2013; Shirodkar and Mohr 2015; White et al. 2015). Corporate political activity (CPA) scholarship demonstrates that governments represent major sources of uncertainty, mainly as they have the power and authority to shape firms' competitive environments (Baron 1995; Weidenbaum 1980). This notion is even stronger in emerging countries where firms are exposed to investment climate constraints stemming from institutional voids (Khanna et al. 2005; Puffer et al. 2010), where governments act in the presence of weak checks and balances and wield significant power which allow them to control critical resources (Li and Zhang 2007; Peng and Luo 2000), and where there are more frequent profound and rapid environmental changes that significantly affect the value of firms' political embeddedness (Siegel 2007; Sun et al. 2010). Therefore, in the face of such challenging investment climates "in emerging economies, resource dependencies on the government are stronger" (Mellahi et al. 2016; p. 156) and it is imperative for firms in these markets to design and use political strategies in order to prosper or even survive (e.g., Dieleman and Boddewyn 2012; Kostka and Zhou 2013; Peng and Luo 2000).

Foreign firms in emerging countries are exposed to and must address two types of investment climate constraints: Administrative constraints and control constraints (Asiedu and Lien 2004; Bitzenis et al. 2012). Drawing upon the World Bank Enterprise Survey (World Bank 2013), administrative constraints can be defined as the obstacles that arise from weak and fledgling administrative institutions or unclear and ill-enforced administrative principles (e.g. corruption, bureaucracy, discrimination), while control constraints are the obstacles emanating from government's direct imposition of drastic measures to manage macroeconomic stability (e.g. import/export restrictions, foreign exchange controls, profit repatriation restrictions). The CPA literature provides significant support for the view that administrative constraints such as corruption (Brockman et al. 2013; Luo 2006) and control constraints such as limited economic freedom and capital controls (Blumentritt 2003) increase pressure on foreign firms to engage in nonmarket activities, particularly the development of political ties. However, the CPA scholarship has focused on firm strategies for addressing specific aspects of investment constraints and has failed to investigate how political strategies are affected when firms are faced with both administrative constraints and control constraints. Consequently, we have almost no knowledge of the relative influence of these two types of constraints, as perceived by managers, on the development of political ties by foreign firms in emerging markets. An understanding of the varied effects of the two types of investment climate constraints is important because they pose strategic challenges which require nonmarket responses from firms (Heidenreich et al. 2015; Nell et al. 2015).

In emerging markets, informal political ties are commonly used by firms to overcome weak market supporting institutions (Acquaah 2007; Park and Luo 
2001; Xin and Pearce 1996). The literature on determinants of CPA offers various typologies of political strategies that MNEs can use to shape their business environments. These strategies range from buffering to bridging (Meznar and Nigh 1995), bargaining to non-bargaining (Boddewyn and Brewer 1994) and reactive to proactive (Oliver and Holzinger 2008). However, the most popular strategies that are studied-the financial, information and constituency-building strategies propounded by Hillman and Hitt (1999)_are based on empirical findings in developed country contexts. In emerging countries, most of Hillman and Hitt's strategies are difficult to use by firms because the institutional environments in these countries offer few or no opportunities for their deployment (Rajwani and Liedong 2015). As a result, informal political ties remain the crucial effective strategy for firms to overcome weak institutions (Acquaah 2007; Park and Luo 2001; Xin and Pearce 1996). While it has recently been argued that advancements in some emerging countries have increased the scope for different political strategies (Shirodkar and Mohr 2015), we posit that this may be the case for a few countries where the institutional environment has been undergoing important transformations (most notably, China and India) but it may not be the case in other countries where such transformations have failed. Hence political ties are still the dominant political tactic in the developing world, especially in SubSaharan Africa.

Africa is increasingly becoming attractive to multinational firms, but management issues in the region are still under-researched (George et al. 2016; Klingebiel and Stadler 2015; Mellahi and Mol 2015). Africa remains particularly under-explored in the area of CPA research. Extant research on the antecedents of political strategies has mainly focused on US firms (e.g., Meznar and Nigh 1995; Schuler 1996), US subsidiaries in Western Europe (Hillman 2003; Hillman and Wan 2005; Wan and Hillman 2006), and foreign subsidiaries in Asia (Shirodkar and Mohr 2015; White et al. 2015). Majority of the published empirical research on the antecedents of CPA in emerging markets have focused on China (e.g., Kostka and Zhou 2013; Mondejar and Zhao 2013; Park and Luo 2001), a country with very distinct institutional characteristics. As a result, we know relatively little about other countries that are characterized by very different market and nonmarket environments. Specifically, the lack of CPA research on Africa prevents us from seeing the larger emerging market picture. We know that institutional voids in African economies pose significant investment constraints for firms (Bah and Fang 2015). What we do not know, however, is how these constraints affect CPA.

Further, the role of public affairs (PA) functions or departments in political strategy formulation is poorly understood. Even though these functions serve as crucial links between firms and their external environments (Doh et al. 2014; Griffin and Dunn 2004), they have not received adequate attention. In other words, researchers have done little to differentiate between PA functions and CPA or even to understand the impact of PA functions on nonmarket strategy. These functions could facilitate the formalization or structuration of CPA, which can affect the scope, intensity or effectiveness of political strategies (Schuler 1996). Foreign firms operating in emerging countries may have to establish PA departments to manage their interactions with political decision makers in order to gain legitimacy, hence it is important 
to understand whether and how PA functions affect political tie development and strength.

In this study, we fill the gaps above by examining the effects of managers' perceptions of two investment climate constraints, namely administrative constraints and control constraints, on political tie intensity in Ghana, Africa. Based on previous studies (Danis et al. 2010; Li and Zhang 2007), we define political tie intensity as the extent to which senior managers develop and maintain informal ties to politicians. Our data reveals that while control constraints incentivise political tie intensification, administrative constraints have the opposite effect. We also uncover evidence of moderating and possible substitution effects for PA functions.

We set this study in Ghana for theoretical and empirical reasons. According to the World Bank and IMF, Ghana was the fastest growing African economy in 2011. While not the largest economy on the continent, Ghana is an attractive destination of foreign direct investment. Data from the United Nations Conference on Trade and Development (UNCTAD) shows that Ghana ranked sixth in Africa for cumulative FDI inflows between 2000 and 2015. In 2015, FDI accounted for 9.05\% of Ghana's GDP, which is a larger contribution when compared to 44 other African countries including Nigeria, Egypt and South Africa-the largest economies in the region. Foreign firms' participation in Ghana is therefore unquestionable.

Despite being attractive to foreign investors, Ghana is fraught with investment challenges. According to the World Bank (2017), Ghana ranks 108th out of 190 countries for ease of doing business, which is lower than most of the emerging Asian countries that frequently feature in international business research (e.g. Taiwan, China, Malaysia, Philippines, Singapore, etc.). It also ranks 154th for trading across borders (i.e. time and cost to export or import) and 155th for resolving insolvency. With respect to global competitiveness, Ghana lags behind other lower middle income countries in the world, ranking 114th out of 138 countries globally (Schwab 2016).

Considering that managerial ties become less valuable as institutions becomes stronger (Sheng et al. 2011), political ties could be more important in Ghana than in emerging Asian countries such as China, Brazil and India which have witnessed significant transitions and institutional development over the years. Firms in Ghana utilize business and political ties (Acquaah 2007; Boso et al. 2013), which could be the result of the persistent investment constraints in the country.

This study makes significant contributions to the CPA and international business literature. First, it adds to our knowledge of the antecedents of political strategies. By examining how perceptions of managerial assessment of different types of institutional arrangements in emerging countries affect political tie intensity, we offer insights into how challenges in international markets trigger MNE political behaviour. Though prior studies have covered the institutional determinants of political strategies (e.g., Hillman and Keim 1995; Hillman 2003; Hillman and Wan 2005), we focus on two different types of investment challenges which we classify, disaggregate and study to show the nuance in the effects of administrative and control constraints on the development of political ties in emerging markets. The findings reveal respective positive and negative effects of control and administrative constraints on political tie intensity, and show that not all institutional challenges lead to CPA, 
contrary to what the extant literature suggests (e.g., Hillman et al. 1999; Kingsley et al. 2012). Second, this study contributes to the nonmarket strategy literature by addressing the neglected role of the PA function in foreign firms. While the literature postulates that PA functions are important vehicles for CPA (Post et al. 1982; Martin 1995; Doh et al. 2014), our study shows that PA functions have a negative direct effect and a positive moderating effect on political ties, which does not only suggest that PA functions and political ties could be substitutes, but also indicates that PA functions have double-edged implications for CPA. Finally as this study is set in Africa, an empirical blind spot in international business research (Chang et al. 2010), it also makes a contextual contribution to both CPA and international business literatures.

The rest of the paper is structured as follows. In the next sections, we review literature on the antecedents of CPA and develop our hypotheses. We then describe our methodology and present our findings. We conclude by discussing the study's contribution and suggesting avenues for future research.

\section{Literature Review and Hypotheses}

There is a vast body of literature on the antecedents of corporate political strategies (Hillman et al. 2004; Lux et al. 2011). At the firm level, studies have drawn upon resource-based view and resource dependency logics to show how firm-strategic factors influence CPA. At this level, size seems to be the foremost determinant of CPA (Hillman et al. 2004; Wan and Hillman 2006). Other determinants include dependency on tangible versus intangible resources (Shirodkar and Mohr 2015), dependency on revenue from governments (Hansen and Mitchell 2000) and firm age which is often used as a proxy for credibility or reputation (Hillman 2003). At the industry level, structural issues such as concentration and size reportedly influence the political activity of firms, inter alia firms in small or concentrated industries are arguably in positions which enable them to organize collective actions, present unified and stronger political positions to government, identify and exclude free-riders, or gain the larger share of political benefits (i.e. the industry leaders), and are therefore more likely to utilize political strategies (Grier et al. 1994; Schuler et al. 2002b; Schuler 1996). Likewise, intra-industry dynamics play a role, including most notably the interactions between the firm's CPA and the CPA of industry competitors (Gray and Lowery 1997; Schuler et al. 2002a). At the institutional level, research has shown that differences in institutional elements can affect CPA (Schuler et al. $2002 b$ ), with the majority of studies generally focusing on international firms, specifically foreign subsidiaries. At this level, scholarship shows inter alia that corporate political strategies depend on specific environmental conditions such as national culture (Hillman and Wan 2005), political systems (Hillman and Keim 1995), hostcountry economic freedom (Blumentritt 2003), and host-country regulatory quality (Wan and Hillman 2006).

Within this literature, the interactions between investment climate constraints and CPA have received significant attention because of their impact on organizational performance (e.g., Holburn and Zelner 2010; Lawton et al. 2013a). CPA 
scholarship provides substantial evidence that different challenges such as corruption, legal uncertainty, high incidence of government contract repudiation or arbitrary application of rules cause uncertainty and create an environment in which firms are pressured to develop nonmarket strategies, most notably, the development of political ties (Brockman et al. 2013; Mondejar and Zhao 2013; Wan and Hillman 2006; White et al. 2015). Yet, research has yet to empirically examine how different types of investment climate constraints affect CPA, especially in emerging countries which are fraught with these constraints (Luo 2006). It is reasonable to assume that different types of investment constraints may give rise to different political strategies-including varying levels of political tie intensity, just as different types of institutional uncertainty reportedly discourage investment to varying degrees (García-Canal and Guillén 2008) and just as firms may respond differently to institutional uncertainty because of their political ties or their capabilities to assess policy risks (e.g., Frynas et al. 2006; Holburn and Zelner 2010). The CPA scholarship has failed to disaggregate between the impact of administrative and control constraints on political strategies and we have no knowledge of the relative influence of these two types of constraints on the development of political ties by firms in emerging markets, a gap that this study aims to fill.

While the development of political ties can be crucial for a firm's success in emerging markets, we know very little about how firms internally organize their activities to manage political ties. The CPA literature has provided a wealth of knowledge of what sort of political resources and capabilities are needed in the development of political strategies and the organizational performance thereof (Mellahi et al. 2016; Rajwani and Liedong 2015), but how these resources and capabilities are actually organized inside the firm has been barely investigated. As one recent nonmarket strategy study noted, "while the RBV has given us theories on how and why a firm's resources provide the foundations of competitive advantage, the strategic process by which the firm manages the composition and structure of the resource portfolio remains somewhat of a 'black box'" (Lawton et al. 2013b, p. 230). PA functions may provide the key for addressing this 'black box' to understand how political capabilities are organized (e.g., Lawton et al. 2013b). However, it is important, and indeed necessary, to first understand the relationship between PA functions and political connections before delving into the processes.

Consequently, several recent studies have investigated a number of aspects of the internal organizational structures which underpin or moderate the development of nonmarket strategy, including the internal organization of the PA function (Doh et al. 2014) and the nature of the internal relationships between public affairs managers and colleagues in other subsidiaries (Barron et al. 2017). Most pertinent to our enquiry, scholars indicated a long time ago that CPA could be contingent on PA functions (Martin 1995; Schuler 1996). However, the role of PA functions in nonmarket strategy and international business has largely been overlooked in the literature. Researchers have done little to differentiate between PA functions and CPA or even to understand the impact of PA functions on nonmarket strategy. The few existing studies on the PA function in developed countries provide contradictory evidence. For example, Martin (1995) found that US companies with a government affairs office in Washington, D.C. had different CPA priorities (in this case, a 


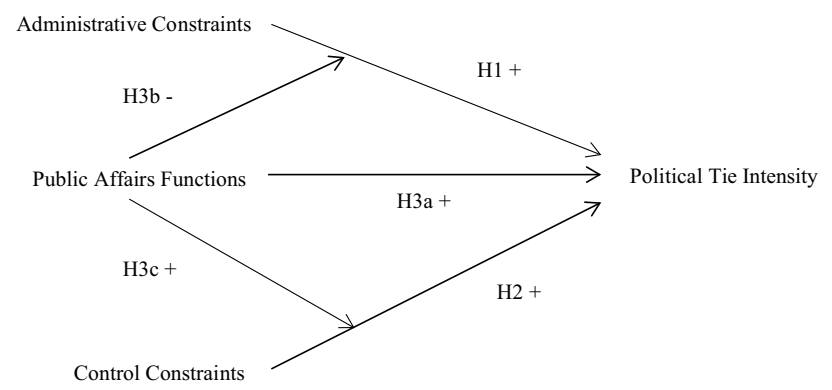

Fig. 1 Research model

different level of support for health care reform) than those companies without such an office, while Schuler (1996) did not find a significant relationship between having such an office and petitioning. A rare recent study found that the creation of a unified PA function helped Lufthansa to develop effective new political activities at EU level, while the creation of a similar PA function at Tata Consultancy Services had few consequences for political activities because its remit was largely limited to social and environmental activities (Doh et al. 2014). In effect, the existing studies are inconclusive and have failed to establish to what extent PA functions facilitate the intensification of political ties among foreign firms, especially in emerging countries.

Our study is positioned to address the gaps above, as we examine how managerial perceptions of investment climate constraints influence the political tie intensity of foreign firms in Ghana. Next, we present the empirical framework of our study (Fig. 1) and develop hypotheses predicting how control constraints and administrative constraints affect the intensity of political ties among foreign firms.

\subsection{Administrative Constraints and Political Tie Intensity}

Some of the common investment climate constraints faced by firms, especially foreign firms in emerging countries, are rooted in weak administrative institutions which fail to stamp out bribery and corruption or reduce red-tape and bureaucracy. Corruption is highly pervasive in Africa (Luiz and Stewart 2014). Being very common in most countries on the continent, corruption seems to have become an institution of its own (van den Bersselaar and Decker 2011), with dire consequences for firms. Bureaucratic red-tape and slow public sector systems can lead to delays in shipments and approvals, problems in the administration of taxes and licenses, and increased time costs for managers, thereby decreasing efficiency (Faruq et al. 2013). Red-tape also exacerbates the problem of corruption, as individuals and firms are expected to make informal payments in order to receive preferential and expedite treatment. For foreign firms to succeed in weak institutional environments, they need to adapt and appreciate the structure of such administrative lapses (Rodriguez et al. 2005). In host countries where there is high level corruption, there is increased 
pressure for foreign firms to engage in corrupt practices (Spencer and Gomez 2011), arguably for institutional legitimacy reasons (Ahlstrom and Bruton 2001).

Administrative constraints affect political tie intensity in two ways. On the one hand, the negative consequences of these constraints motivate the strengthening of political ties. For instance, corruption increases the cost of doing business (Wei 2000), lowers firm growth (Fisman and Svensson 2007), and requires managerial attention and effort to manage and deal with corrupt officials (Svensson 2005; Cuervo-Cazurra 2016). Additionally, high incidence of government contract repudiation or arbitrary interpretation or application of rules creates uncertainty (Spencer and Gomez 2011; Ahlstrom and Bruton 2001). Consequently, firms will strengthen their ties to politicians in order to successfully navigate extortions and other administrative obstacles (Xin and Pearce 1996). As noted by Wan and Hillman (2006), administrative discretion is an incentive for firms to use personal connections to influence politicians who have discretion over their operations. Moreover, the effort exerted to manage corrupt officials increases interactions between managers and politicians, which further strengthens or intensifies firms' political ties.

On the other hand, administrative constraints such as corruption offer opportunities for foreign firms to internalize or co-opt government officials (Boddewyn 1988; Sun et al. 2010). The opportunity to pay bribes to expedite paperwork, get a government contract, access private information or avoid regulatory penalties can enable firms to differentiate themselves and gain a competitive advantage. A recent review of nonmarket strategy literature reveals that political ties are more valuable in environments with high corruption (Rajwani and Liedong 2015). This positive institutional moderation is a strong motivator for foreign firms to intensify their political ties in order to benefit from discretionary policymaking (García-Canal and Guillén 2008), arbitrary variation of rules and expedition of bureaucratic processes, especially for permits (Lui 1985). Taking the above arguments into consideration, we advance that both the threats and opportunities created by administrative obstacles offer incentives for foreign firms to engage politically, and hence propose that:

H1: In an emerging market environment, administrative constraints incentivise foreign firms to intensify their political ties.

\subsection{Control Constraints and Political Tie Intensity}

In emerging countries, governments sometimes use various controls to ensure macroeconomic stability. These controls include import/export restrictions, trade quotas and price ceilings, as well as constraints on capital flows such as foreign exchange controls and profit repatriation restrictions. Controls were widely used prior to the 1970s but the pressures of economic integration and trade liberalization, championed by the Bretton Woods institutions, reduced their usage (Johnson and Mitton 2003). Nevertheless, emerging countries still implement controls to manage crises for which conventional policies are ineffective (Grabel 2016). For instance, the government of Nigeria recently implemented severe foreign exchange restrictions to 
arrest the free fall of the Naira. In recent past, the government of Ghana also took similar measures to curtail adverse speculative effects on the Cedi.

Though control constraints have adverse effects on local firms, foreign firms are likely to be affected most. For example, capital controls increase the cost of local borrowing for foreign firms, since international inflows are not available to reduce or equalize local interest rates (Dooley and Isard 1980). Restrictions on repatriation of profits also reduce the return on investment for foreign investors (Desai et al. 2006). Moreover, the various measures used by firms to circumvent these controls, such as earnings management and transfer pricing, require additional managerial effort, are risky and thus costly. These ramifications are therefore expected to spur interactions between foreign firms and government officials, and culminate in the intensification of political ties. As research shows that political connections are associated with preferential access to finance and lower interest rates (Khwaja and Mian 2005; Claessens et al. 2008; Houston et al. 2014; Chen et al. 2014), foreign firms exposed to control constraints can reduce their cost of local borrowing by developing and intensifying their ties to politicians. Intense connections to politicians may also reduce the need for earning managements since connected firms enjoy protection from expropriation (Batta et al. 2014; Nee 1992).

More importantly, controls allow politicians to redistribute resources across firms (Rajan and Zingales 2003), and in the redistribution process, cronyism becomes predominant as politically connected firms are given preferential treatment (Johnson and Mitton 2003; Desai et al. 2006; Desai and Olofsgard 2011). Firms on the receiving side of capital reallocations can enjoy unrivalled performance and competitive advantage. We argue that in the presence of control constraints, the opportunity to benefit from favouritism, exclusivity, and exceptions is an important inciting factor for the intensification of political ties among foreign firms. We therefore propose that:

H2: In an emerging market environment, control constraints incentivises foreign firms to intensify their political ties.

\subsection{Public Affairs Functions and Political Tie Intensity}

PA functions are channels for interactions between firms and their external environments (Griffin and Dunn 2004). They place significance on developing and managing beneficial relationships with key institutional stakeholders such as government officials, civil society and communities (Lawton et al. 2014). These functions increase the external visibility of firms, lead to managerial recognition and prestige, and make it relatively easier for managers to develop and intensify their ties to politicians. In other words, the manager of a highly visible firm will require less effort to connect with politicians than a manager of an unknown or invisible firm. This logic is supported by social identity theorists who note that organizational visibility confers prestige and respect on employees (Fuller et al. 2006) and that perceptions of self-worth are affected by the level of respect for the group to which one belongs (Tyler et al. 1996). In this sense, we argue that managers will use the visibility and 
status of their organizations to enhance their self-esteem, boost their confidence to engage with the polity, and consequently intensify their political ties.

Moreover, countries have distinct external institutional environments (Kostova and Zaheer 1999) and distinct sets of institutional logics, rules and arrangements regarding the conduct of business (Zaheer and Zaheer 1997). This institutional environment is created inter alia by government policy and regulations (Murtha and Lenway 1994) and through the social relationships of local legitimizing actors such as suppliers, legislative authorities, and research institutes (Chan and Makino 2007). Firms are expected to follow the rules and norms of their host countries in order to gain legitimacy (Yiu and Makino 2002), an important requirement for success in emerging markets (Ahlstrom and Bruton 2001; Zheng et al. 2015). As the management of legitimacy relies on communication between firms and legitimizing actors (Suchman 1995) - a purpose served by PA functions-we propose that these functions can confer legitimacy and therefore directly intensify the connections between firms and the polity.

Beside PA functions having a direct impact on political tie intensity, they also have moderating influences on the relationships between control constraints, administrative constraints and political tie intensity. With respect to administrative constraints, we propose that the visibility effects of PA functions will have a weakening impact on political tie intensity through two mechanisms. First, highly visible firms are more socially responsible (Jia and Zhang 2015) because visibility increases corporate vulnerability to external scrutiny (Chiu and Sharfman 2011; Meznar and Nigh 1995) and leads to a high propensity for firms to become sensitive to social and political stakeholders (Brammer and Millington 2006; Saiia et al. 2003). We posit that even though administrative constraints provide competitive opportunities that can be exploited through political connections (Rajwani and Liedong 2015), high visibility and external scrutiny will deter managers from exploiting those opportunities. Involvement in corrupt practices and unethical behaviour will have more reputation damaging effects on highly visible firms than invisible firms (Udayasankar 2008; Yu et al. 2017), and this is expected to reduce managerial commitment or desire to use political ties to exploit the potential opportunities created by administrative constraints.

Second, research shows that highly visible firms are able to resist stakeholder pressures, such as the pressure to participate in CSR (Darnall et al. 2010; Yu et al. 2017). This resistance could be attributed to resource-endowment, legitimacy and public goodwill which are often associated with visibility (Yu et al. 2017). Based on these prior findings, we argue that high visibility can also help firms to resist pressures to pay bribes, mainly as PA functions offer various channels through which firms could make damning extortionist revelations that could damage the reputations of corrupt public officials. In other words, high visibility through media relations, corporate communications and periodic events could deter public officials from subjecting firms to unnecessary bureaucracy or demand for informal payments, which will reduce the negative effects of administrative constraints and consequently weaken the need to develop strong political ties.

With respect to control constraints, we advance that PA functions are formalized and integrated into the structures of organizations (Blumentritt 2003). They 
represent an institutionalization of external assessment and engagement (Kobrin 1982), and thus indicate the extent of corporate commitment to external participation in social, economic and political issues (Greening and Gray 1994; Schuler 1996). Firms with dedicated PA functions "can achieve more effective and strategic actions and policies, ultimately serving to advance their competitive advantage" (Doh et al. 2014, p. 97). Having already argued that control constraints create opportunities and threats which can incite managers to develop political ties, we propose that PA functions enable firms to formally assess and amplify the opportunities or threats they face, which can further intensify their CPA (Lawton et al. 2013b). In this respect, PA functions can support a comprehensive formal evaluation of the often-poor institutional conditions in emerging markets, which creates a clearer picture of the negative effects of control constraints and portrays a stronger need for intense political ties. Therefore, we propose the following:

H3a: In an emerging market environment, public affairs functions facilitate the intensification of political ties among foreign firms.

H3b: In an emerging market environment, public affairs functions weaken the positive impact of administrative constraints on political tie intensity among foreign firms.

H3c: In an emerging market environment, public affairs functions strengthen the positive impact of control constraints on political tie intensity among foreign firms.

\section{Methodology}

\subsection{Empirical Setting}

Ghana provides a suitable context for studying a full range of investment constraints. Corruption and other administrative obstacles are highly prevalent in the Ghanaian society (see Heidenreich et al. 2015). The 2016 Corruption Perception Index (CPI) shows that the level of corruption in Ghana has increased over the years, which partly explains why an incumbent President, for the first in the country's history, lost the 2016 election. Another recent report by the World Economic Forum ranked Ghana 109th out of 138 countries on a global measure of irregular payments and bribes made in public contracts and transactions (Schwab 2016). Additionally, regulations in Ghana are not always strictly implemented, leading to arbitrariness which creates opportunities for favouritism and cronyism. The State institutions that were set up to fight corruption have not been able to reduce the menace. In the past, corruption mainly followed a traditional model whereby officials demand irregular payments from firms. In recent times however, the model of corruption has changed. In what is termed 'create-loot-share' (Essel 2015; Yeboah 2013), public officials and politicians now award genuine but inflated contracts to firms. The excess funds are then appropriated among the officials and the contracting firms. 
Control constraints are also prevalent in Ghana. Institutional weaknesses in emerging countries often create macroeconomic problems (Acemoglu et al. 2003) which require drastic policy measures (Grabel 2016). In Ghana, weak macroeconomic fundamentals in 2014 caused the government and the central bank to impose foreign exchange controls to stem the free fall of the local currency. In August 2016, a bill was introduced to restrict the importation of certain products and commodities such as cement into the country. Generally, these controls do not favour foreign firms. As there is limited scope for the private sector in emerging countries to comment on bills or lobby for regulations (Rajwani and Liedong 2015), informal political ties are the most likely tactics firms can use to influence government policy, exploit or overcome investment climate constraints in Ghana (see Heidenreich et al. 2015).

\subsection{Data}

Due to a lack of archival information on political ties in Ghana, the data used for this study comes from a survey. We designed a questionnaire which was subjected to a rigorous peer review to check the appropriateness of the constructs and measures. The questionnaire was then pilot tested to ensure that the questions are valid for the Ghanaian business environment (Mesquita and Lazzarini 2008). Consequent of the lack of secondary data in Ghana and the rest of Africa (Klingebiel and Stadler 2015), surveys dominate the management research landscape. The result of this phenomenon is respondent fatigue, organizational disinterest and low response rates. Therefore, to maximize response to our survey, we sought endorsements from the Ghana Investment Promotion Centre (GIPC) and the Association of Ghana Industries (AGI). These organizations were strategically chosen to improve the study's credibility. For instance, GIPC, an agency under the Office of the President of Ghana, is responsible for promoting private sector development and attracting foreign investment into the country.

The data was collected in two stages. In the first stage we sampled 300 firms in 2014, of which 173 were locally owned (50\% or more owned by Ghanaians) and 127 were foreign-owned (more than $50 \%$ owned by foreigners). The firms were selected from the membership directory of AGI, Ghana Business Directory and Ghana Club 100. We collected data from Chief Executive Officers (CEOs), Managing Directors (MDs) and other senior managers. The respondents worked at their firms for an average of 6 years, which suggests they had good knowledge of their organizations. All the selected firms had operated in Ghana for at least 3 years prior to the data collection. This requirement was used because the survey made reference to the past 3 years as the time frame for responses (2011, 2012, and 2013), a strategy used to reduce biased responses based on one-off positive or negative experiences (Mesquita and Lazzarini 2008; White et al. 2015). Due to poor postal services in Ghana, the questionnaires were physically delivered to the offices of the firms. After several follow-ups, we retrieved questionnaires from 188 firms. Nine were poorly completed and unusable. The final sample of 179 firms comprised of 99 locally owned firms and 80 foreign firms. We used the data from the foreign firms, technically resulting 
in a response rate of $62.9 \%(80 / 127)$. The sample consists of firms that operate in 18 industries, including mining (1.3\%), petroleum (20\%), pharmaceuticals $(5 \%)$, and manufacturing $(7.5 \%)$ among others. Descriptively, 56 of the 80 firms had PA functions. This is unsurprising, considering that foreign firms may want to establish relationships with institutional stakeholders in order to mitigate potential liabilities of foreignness. $57 \%$ of the respondents were managing directors and CEOs. The rest (43\%) were general and senior operations managers. In the second stage, we sent out surveys in 2015 to the 80 foreign firms, but only 12 firms responded. $T$ tests did not reveal significant differences between the responses collected in the first and second stages. Consequently, we used the data collected in the first stage.

\subsection{Measures and Variables}

\subsubsection{Dependent Variable}

The dependent variable for this study is political tie intensity $(\alpha=0.91)$. As noted earlier, our conceptualization of this variable is theoretically grounded in the works of Danis et al. (2010) and White et al. (2015). Defining tie intensity as the extent to which managers invest time to nurture and maintain beneficial relationships with other stakeholders in the business environment, we followed Guo et al. (2014), Li and Zhang (2007) and Xin and Pearce (1996) and developed a three-item scale to measure this variable. Respondents were asked to indicate their level of agreement with (a) investing in building ties with government officials, (b) spending time dealing with government officials and (c) making efforts to ensure good relations with government officials. These were measured on a scale ranging from (1) 'strongly disagree' to (7) 'strongly agree'.

\subsubsection{Independent Variables}

The independent variables are control constraints $(\alpha=0.83)$ and administrative constraints $(\alpha=0.79)$. These variables were adapted from the measure of investment climate constraints in the World Bank Enterprise Survey. Control constraints was operationalized as the extent to which government direct controls (i.e. foreign exchange controls, import and export controls, and price controls) pose obstacles to firms' operations whereas administrative constraints was operationalized as the extent to which bureaucracy, bribery, corruption and contract repudiation pose obstacles to firms' operations. Both variables were measured on a scale, ranging from (1) 'strongly disagree' to (7) 'strongly agree'.

\subsubsection{Moderator Variable/Control Variables}

The moderator is $P A$ functions. This variable is defined by a dummy, coded ' 1 ' for firms that have a public/government affairs function or department and ' 0 ' for otherwise. We controlled for other variables that can affect the intensity of political ties. Resource-based view theory suggests that successful firms are more likely to be 
politically active (Hillman et al. 2004; Mitchell et al. 1997; Lux et al. 2011), mainly as high performance avails resources and capabilities for political tie development and intensification. We therefore controlled for this by including the variable Firm Performance $(\alpha=0.94)$ in our analysis. As firms in Ghana are often reluctant to provide financial information to researchers (Amoako-Gyampah and Boye 2001), we followed Acquaah (2007), Guo et al. (2014) and Li and Zhang (2007) and asked respondents to rate the performance of their firms vis-à-vis their competitors on seven items (return on assets, return on equity, return on sales, growth in productivity, growth in market share, growth in sales and growth in net income) on a scale ranging from (1) 'much worse' to (7) 'much better'.

Firm age has been used as a proxy for visibility (Hansen and Mitchell 2000), credibility (Hillman et al. 1999; Hillman 2003), and reputation (Boddewyn and Brewer 1994). Longevity can enable firms to develop important relationships with stakeholders (Acquaah 2007), build strong constituencies (Keim and Baysinger 1988) and intensify their political ties. Following previous studies (Hillman 2003; Acquaah 2007; Wocke and Moodley 2015), we measured Firm Age as the number of years the firm has been operational in Ghana. Firm Size is an antecedent of CPA (Hillman et al. 2004; Schuler et al. 2002a) and a proxy for resource endowment (Boddewyn and Brewer 1994; Hillman and Hitt 1999). The possession of vast resources can help firms to intensify their political ties. Following previous studies (Peng and Luo 2000; Acquaah 2007; Yiu et al. 2007) and normality tests, firm size was operationalized as the logarithm of the number of employees. Highly regulated firms have a higher tendency to be politically active, as they have high stakes in government actions and inactions (Grier et al. 1994). Following Hadani and Schuler (2013), regulation is defined by a dummy, coded ' 1 ' for firms operating in highly regulated industries (telecommunications, mining, oil and gas, chemicals, pharmaceuticals, utilities) and ' 0 ' for otherwise.

\subsection{Validity and Reliability}

It is difficult to totally avoid common method variance (CMV), especially "if research probes into difficult waters where data of any kind are scarce such as in severely understudied parts of the world (Africa, the Middle East)" (Chang et al. 2010, p. 182). Nevertheless, we made attempts to reduce CMV using various techniques. First, we worded the questions carefully to reduce social desirability bias associated with political ties. Second, we reverse-phrased some of the questions in order to reduce acquiescence bias whereby respondents agree or disagree with statements without scrutiny (Winkler et al. 1982; Hinkin 1995). Third, we mixed the order of the questions so that the dependent and independent variables do not follow sequentially. This was intended to make it difficult for respondents to anticipate or create variable correlations that can bias their responses (Chang et al. 2010; Wiklund and Shepherd 2005). Fourth, we delivered two surveys to two senior managers in every sampled firm in order to address single-rater bias (Podsakoff et al. 2003). Only four foreign firms returned both questionnaires and we tested inter-rater agreements using Cohen's kappa which showed significant similarity among the managers. This 
Table 1 Constructs, measures and reliability

\begin{tabular}{|c|c|c|c|}
\hline Construct & Measurement items & Load & $\mathrm{T}$ value \\
\hline \multicolumn{4}{|l|}{ Political tie intensity } \\
\hline \multirow[t]{3}{*}{$(\mathrm{AVE}=0.77 ; \mathrm{CR}=0.91)$} & Spending time dealing with gov't affairs & 0.89 & 10.40 \\
\hline & Investing in building relationships with gov't officials & 0.88 & (Fixed) \\
\hline & Maintaining good relationships with gov't officials & 0.87 & 10.21 \\
\hline \multicolumn{4}{|l|}{ Administrative constraints } \\
\hline \multirow[t]{3}{*}{$(\mathrm{AVE}=0.52 ; \mathrm{CR}=0.86)$} & Obstacles posed by corruption and bribery & 0.91 & (Fixed) \\
\hline & Obstacles posed by bureaucracy or red tape & 0.72 & 3.82 \\
\hline & Obstacles posed by contract repudiation & 0.63 & 3.52 \\
\hline \multicolumn{4}{|l|}{ Control constraints } \\
\hline \multirow[t]{3}{*}{$(\mathrm{AVE}=0.54 ; \mathrm{CR}=0.87)$} & Obstacles posed by import and export controls & 0.95 & (Fixed) \\
\hline & Obstacles posed by currency controls & 0.70 & 3.36 \\
\hline & Obstacles posed by price controls & 0.66 & 2.74 \\
\hline \multicolumn{4}{|l|}{ Firm performance } \\
\hline \multirow[t]{7}{*}{$(\mathrm{AVE}=0.71 ; \mathrm{CR}=0.94)$} & Growth in sales & 0.98 & 15.05 \\
\hline & Growth in market share & 0.89 & (Fixed) \\
\hline & Growth in productivity & 0.88 & 11.7 \\
\hline & Growth in net income & 0.86 & 11.07 \\
\hline & Return on assets & 0.82 & 10.13 \\
\hline & Return on sales & 0.78 & 9.15 \\
\hline & Return on equity & 0.66 & 6.95 \\
\hline
\end{tabular}

$A V E$ average variance extracted, $C R$ composite reliability

finding suggests that the rest of the data from single respondents is reliable, just as previous studies have used single respondents for organizational studies (Peng and Luo 2000; Li and Zhang 2007; White et al. 2015). Fifth, we performed the Harman's single factor test by conducting exploratory factor analysis (EFA) to identify the factor structure of the data. Our analysis revealed five factors which together accounted for $78.06 \%$ of the variance. The first factor contributed $31.14 \%$ of the total variance (which is less than even half of the total variance), thus suggesting that a single factor problem does not affect the data. Sixth, even though it was difficult to obtain secondary data, we triangulated some of the primary data such as firm age and firm size using information from secondary sources such as company websites and reports (Liedong and Rajwani 2017). Finally, we included moderation effects in the analyses to reduce the effect of CMV, as complex interactions are not predicted by CMV (Chang et al. 2010). We tested for non-response bias using the approach of Armstrong and Overton (1977) whereby we compared early and late-arriving completed surveys. $T$ tests revealed no significant difference for any key items or variables, thus ruling out the existence of systemic non-response bias.

We also conducted confirmatory factor analyses and found a satisfactory fit. We checked discriminant validity by comparing the square root of the average variance explained (AVE) of each construct with the correlation between the constructs (Murray et al. 2005). As the AVE values are larger than the correlations between the 
constructs, each variable has more internally extracted variance than the variance it shares with other variables (Fornell and Larcker 1981), thus indicating satisfactory discriminant validity. High standardized factor loadings of the items on their underlying or expected constructs (above 0.50), high AVEs above 0.50, and high composite reliabilities above 0.70 , as shown in Table 1 , demonstrate convergent validity (Fornell and Larcker 1981; Hair et al. 1998; Murray et al. 2005). Internal consistency was measured for all scales using Cronbach's alpha. A coefficient of 0.70 is typically considered adequate (Nunnally 1978). All of our scales have reliability scores above this threshold.

\section{Analysis and Results}

To establish association between political tie intensity and investment climate constraints, we performed hierarchical regression analyses. To ensure that our analysis is robust, we ran casewise diagnostics to check the residuals for bias. The results show that around $95 \%$ of the cases have standardized residuals within the criterion, a finding consistent with ordinary samples (Field 2013). We also checked whether any cases exert undue influence over the parameters of the Models by analysing Cook's distances (Cook and Weisberg 1982). We found no influential cases. Before creating our interaction terms, we mean centred the variables (lower-order terms) before creating the interactions (higher-order terms) (Aiken and West 1991; Cohen et al. 2003).

To further check robustness, we performed bootstrapped regressions using an iterated sample of 1000 and estimating a 95\% bias corrected and accelerated confidence interval for the coefficients. The significance of the coefficients did not change dramatically in the bootstrapped Models, indicating that they are an accurate estimate of the true population (Field 2013). Additionally, we checked for autocorrelation of the residuals of the predictor variables using the Durbin-Watson test (Durbin and Watson 1951). The result for all the Models is closer to ' 2 ', indicating that serial correlation does not affect the robustness of the findings. This approach showed that endogeneity from auto-regression or autocorrelation does not affect the findings of our study. There were no problems of multicollinearity as the Variance Inflation Factors (VIFs) were less than 10 (Bowerman and O'Connell 1990). In fact, the highest VIF is 1.71.

Descriptive statistics and the correlation matrix are shown in Table 2. Though there are significant correlations between some of the variables, the coefficients are not very large to suggest the existence of multicollinearity. The mean value for political tie intensity (3.78) exceeds the average value of the scale (i.e. 3.5), indicating that there is a high tendency for foreign firms in Ghana to develop political ties. Also, a large proportion of these firms have PA functions, obviously to engage with institutional actors and gain legitimacy.

Table 3 shows the regression results. In Model 1 where the control variables are tested, the findings confirm the significance of resource-based antecedents of CPA (Hillman et al. 2004; Lux et al. 2011). Specifically, the results show positive associations between firm performance, firm age and political tie intensity, and are 


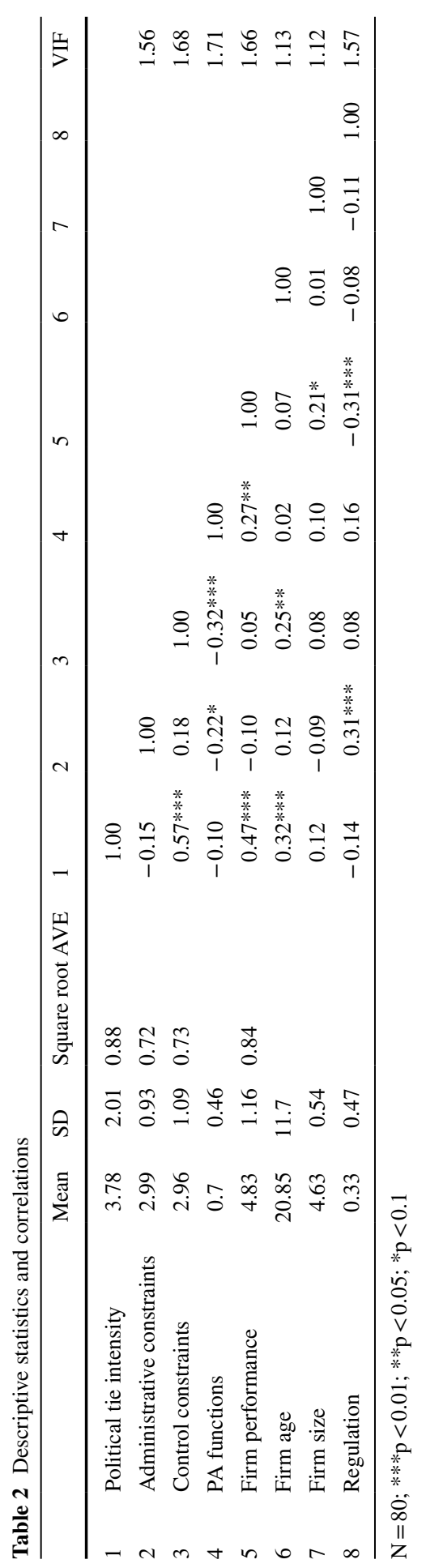


Table 3 Regression results

\begin{tabular}{|c|c|c|c|c|c|c|}
\hline & \multicolumn{6}{|c|}{ Political tie intensity } \\
\hline & Model 1 & Model 2 & Model 3 & Model 4 & Model 5 & Model 6 \\
\hline \multicolumn{7}{|l|}{ Control variables } \\
\hline Firm size & 0.09 & -0.14 & 0.15 & -0.09 & -0.21 & -0.21 \\
\hline Firm age & $0.05 * * *$ & $0.03 * *$ & $0.05 * * *$ & $0.04 * *$ & $0.04 * * *$ & $0.04 * * *$ \\
\hline Firm performance & $0.78 * * *$ & $0.73 * * *$ & $0.94 * * *$ & $0.83 * * *$ & $0.76^{* * *}$ & $0.78 * * *$ \\
\hline Regulation & 0.13 & 0.17 & 0.45 & 0.44 & 0.31 & 0.33 \\
\hline \multicolumn{7}{|l|}{ Predictor variables } \\
\hline $\begin{array}{l}\text { Administrative constraints } \\
\text { (AC) }\end{array}$ & & $-0.53 * * *$ & & $-0.60 * * *$ & $-0.60 * * *$ & $-0.58 * * *$ \\
\hline Control constraints (CC) & & $1.01 * * *$ & & $0.91 * * *$ & $0.76^{* * * *}$ & $0.76^{* * * *}$ \\
\hline \multicolumn{7}{|l|}{ Contingency variable } \\
\hline Public affairs (PA) & & & $-1.19 * * *$ & -0.66 & -0.41 & -0.42 \\
\hline \multicolumn{7}{|l|}{ Interactions } \\
\hline $\mathrm{AC} \times \mathrm{PA}$ & & & & -0.06 & & -0.11 \\
\hline $\mathrm{CC} \times \mathrm{PA}$ & & & & & $0.64 *$ & $0.65 *$ \\
\hline \multicolumn{7}{|l|}{ Model stats } \\
\hline Adjusted $\mathrm{R}^{2}$ & 0.26 & 0.56 & 0.32 & 0.57 & 0.59 & 0.58 \\
\hline $\mathrm{R}^{2}$ change & $0.30 * * *$ & $0.30 * * *$ & $0.06 * * *$ & 0.00 & $0.02 *$ & 0.02 \\
\hline Model F & $8.00 * * *$ & $17.86 * * *$ & $8.44 * * *$ & $13.85 * * *$ & $15.04 * * *$ & $13.20 * * *$ \\
\hline
\end{tabular}

$\mathrm{N}=80 ; * * * \mathrm{p}<0.01 ; * * \mathrm{p}<0.05 ; * \mathrm{p}<0.1$ Two tailed significance tests

therefore consistent with prior evidence that long existence is a measure of credibility and a determinant of political activity among foreign firms (Hillman 2003; Hillman and Wan 2005). In Ghana where the institutions are weak, long existence does not only give foreign firms credibility and legitimacy, but it also enables them to learn and understand the political landscape, and thus facilitates the development and enhancement of political ties.

In Model 2, we tested hypotheses 1 and 2, which predict that perceptions of administrative constraints and control constraints will respectively lead to political tie intensification. The results show that, indeed, control constraints incite foreign firms to intensify their political ties $(b=1.01 ; p<0.01)$. This finding provides support for hypothesis 2 . However, and counter-intuitively, we found a negative association between administrative constraints and political tie intensity $(b=-0.53$; $p<0.01$ ), suggesting that exposure to bribery, corruption and other administrative voids leads foreign firms to lower the intensity of their political ties. The lack of support for hypothesis 2 raises the need for re-considering the political behaviour of foreign firms in weak administrative settings. Relatively, control constraints have a stronger effect than administrative constraints, suggesting that the net effect of institutional constraints (i.e. both control and administrative) on political tie intensity is positive. We noted a significant improvement of the Model statistics when the two independent variables were added. Adjusted $\mathrm{R}^{2}$ increased from 26 to $56 \%$, 


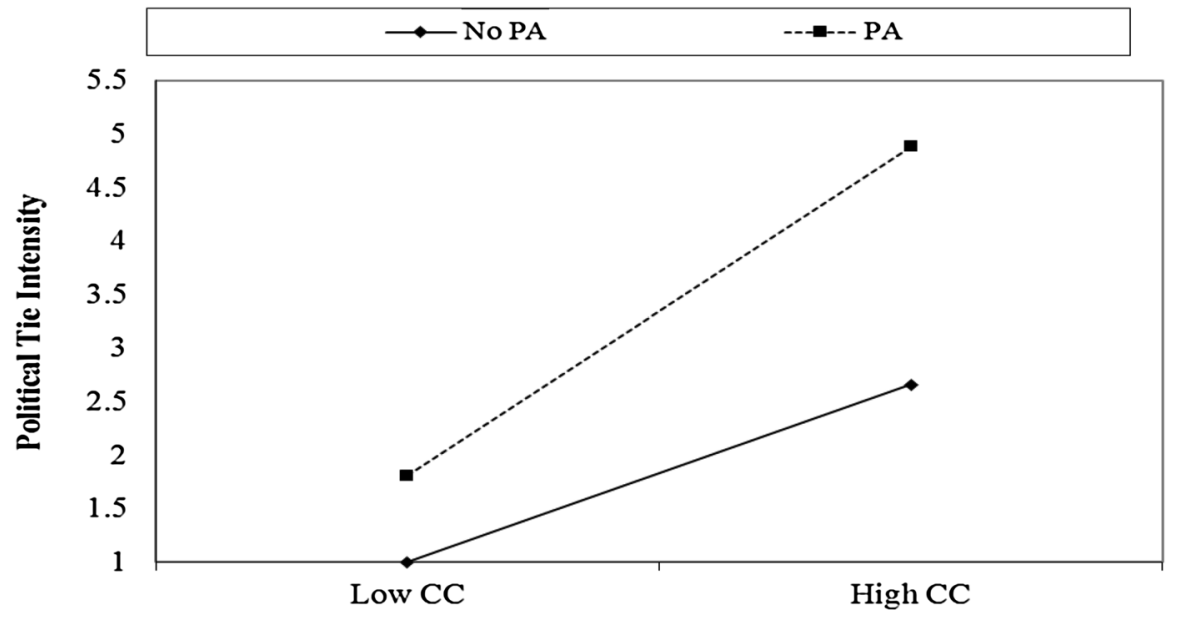

Fig. 2 Interaction effect-PA function and control constraints

confirming the significant effect of administrative and control constraints on political tie intensity.

We introduced the moderator variable, PA functions, in Model 3. Here, the results show that PA functions lead to a significant reduction in the intensity of political ties $(b=-1.19 ; p<0.01)$. This finding contradicts our proposition and hence does not support hypothesis $3 \mathrm{a}$, but it gives credence to a substitution effect between PA functions and relational CPA. Prior evidence shows that firms with Washington offices (equivalent of PA functions) are less likely to send managers to formally testify before congressional committees since they have constant presence in Washington to influence decisions (Schuler 1996).

In Models 4 and 5, we incorporated interactions into the analysis. We predicted that foreign firms that have PA functions and are also exposed to administrative constraints will have weak political ties. The result for the interaction effect is insignificant (Model 4: $b=-0.06 ; p>0.1$ ) and thus warrants no further interpretation. We did not find support for hypothesis $3 \mathrm{~b}$. However, the interaction between PA functions and control constraints is significant (Model 5: $b=0.64 ; p<0.1$ ). Following the rules for interpreting the results of interaction variables that have binary lower-order terms (Hadani and Schuler 2013; Hardy 1993), ${ }^{1}$ we studied the coefficient of the continuous lower-order variable, Control Constraints, and found that it is significant (Model 5: $b=0.76 ; p<0.01$ ). Based on Aiken and West (1991), we further performed simple slopes analysis to see the nature of the interaction (Fig. 2). Together, the findings provide support for hypothesis $3 \mathrm{c}$.

\footnotetext{
1 When an interaction term is constituted by a continuous variable and a binary variable, coefficients on the lower-order continuous term are interpreted as the effect of the continuous variable only and only when the variable is 0 . The results correspond with the group $=0$. Hence, $P A$ functions was reverse-coded prior to creating the interaction terms.
} 


\section{Discussion and Conclusion}

There is a limited understanding of the effects of managerial assessment of institutional environments on political tie intensity and the influence of the PA function on CPA among foreign firms, especially in contexts other than US, Europe and Asia. We addressed this gap by providing empirical evidence on the antecedents of political tie intensity in Ghana, Sub-Saharan Africa. Drawing on institutional theory, we proposed that foreign firms which have PA functions and are exposed to administrative and control constraints will have stronger political ties. We found support for the effect of control constraints, but the other findings are counter-intuitive and thus require closer attention.

Our analysis revealed that exposure to administrative constraints weakens political tie intensity among foreign firms. This finding does not support our proposition that these constraints lead to political tie intensification, mainly as they pose threats that need to be neutralized or provide opportunities that could be exploited (Spencer and Gomez 2011). Nevertheless, a few reasons can be tendered to explicate this contradiction. First, the Political CSR literature notes that multinational firms play an important role in international governance (Frynas and Stephens 2015; Scherer and Palazzo 2007). Besides helping to address institutional voids and improve social welfare (Scherer and Palazzo 2011), these firms are expected to set best practices for the local firms to follow (Rajwani and Liedong 2015). Companies with reputations for socially responsible activities may be reluctant to become involved in political activities (including even government-sponsored sustainability initiatives) because of the perceived risk of later accusations of 'greenwashing' and hypocrisy (Kim and Lyon 2011). Consequently, it is prudent to expect foreign firms operating in weak administrative environments to limit the intensity of their connections to local politicians, since low embeddedness could provide insulation in events of damaging political scandals. This is particularly true for foreign firms that focus more on ethics, as they have a greater propensity to use arm's length bargaining to deal with government affairs (Luo 2006).

Second, corruption is an additional tax which increases the cost of doing business (Cuervo-Cazurra 2016; Fisman and Svensson 2007). Since corruption exists among political elites, it is plausible to posit that stronger political ties will not reduce firms' exposure to demands for irregular payments. In fact, due to the greater need for funds to finance political campaigns or the stronger desire to amass vast wealth to secure lucrative 'pensions' after their political careers, politicians in emerging countries are more likely to demand larger bribes or donations than bureaucrats who experience relatively better job security. This situation is likely to discourage firms from developing and using political ties in response to administrative voids.

Third, volatility in the political landscape of emerging countries could pose a strong disincentive for foreign firms to strengthen their ties to politicians. Companies could lose their political ties due to the departure of politicians or political factions with whom they previously cultivated relations (Darendeli and Hill 2016) and due to potential political and regulatory shocks and evolutionary changes that may lower the value of a firm's existing political ties (Siegel 2007). Strong animosity 
between different political parties in emerging countries, particularly in Africa, can lead to discrimination and political witch-hunting. Political witch-hunting occurs when firms perceived to have connections to previous regimes are penalized by new regimes through contract cancellations, stricter regulations or discrimination. Typically, witch-hunting occurs when new regimes look to establish popular legitimacy by exposing corruption among prior political elites (Henisz and Zelner 2003). Hence, the value of political connections in emerging countries is dynamic (Sun et al. 2010), in the sense that useful ties in previous regimes can become liabilities in later regimes (Leuz and Oberholzer-Gee 2006). In essence, having 'wrong friends' at 'wrong times' negatively affects firms (Siegel 2007). In Ghana for instance, foreign firms decreased their visibility on the political front in the 1960s when signs showed that President Nkrumah's grip on power was untenable (Decker 2011).

When compared, control constraints seem to have a stronger effect than administrative constraints, but this is quite understandable considering that the two sets of constraints have opposing influences on political tie intensity. We advance that there is a strong momentum for foreign firms to deploy political strategies when faced with institutional obstacles (e.g., Nell et al. 2015; White et al. 2015), as is supported by our finding for control constraints. However, because administrative constraints reduce political tie intensity and thus represent an opposing force to this strong momentum, their effect is not as large as that of control constraints. In other words, the tendency for firms exposed to administrative constraints to reduce their political connections may exist, but the strength of this tendency is weaker than the strength of the tendency to develop political ties in response to control constraints. In sum, the net effect is that exposure to investment constraints (i.e. administrative and control constraints combined) has an overall positive effect on political tie intensity.

Surprisingly, we found that foreign firms with PA functions are less likely to have stronger political ties. This result is not only consistent with Schuler (1996) who previously showed that firms with Washington offices are less likely to give congressional testimonies, but it also suggests that PA functions and political ties can be substitutes, not complements, depending on the institutional contingencies. Since PA functions cover business-government relations, civil society relations and philanthropy, it does appear that developing political ties is unnecessary when PAs exist. It is also likely that senior managers delegate the responsibilities and task of dealing with government affairs to PA departments.

Altogether, this study contributes to the CPA literature in significant ways. First, it adds to our knowledge of the antecedents of political strategies by examining how institutional environments in emerging countries affect political tie intensity. Though prior studies have covered some institutional determinants of political strategies (Hillman and Keim 1995; Hillman 2003; Hillman and Wan 2005; White et al. 2015), there is little research on the effect of investment climate constraints on political ties. Consequently, strategy scholars have not made adequate attempts to classify or disaggregate these constraints in order to investigate their potential differential effects on CPA. In our study, we identify two distinct dimensions of investment constraints which are common and important in emerging African economies-administrative and control constraints. Examining them in a common model, our findings reveal that these constraints have different effects on the intensity of political ties. 
Specifically, we found positive and negative effects of control and administrative constraints respectively on political tie intensity. This study sheds light on how corruption and bureaucratic red tape reduce political tie intensity, and shows that not all uncertainties or institutional challenges in emerging countries necessarily cause firms to develop political connections, contrary to what the CPA literature portrays (e.g., Hillman et al. 1999; Kingsley et al. 2012; Lawton et al. 2013a). In that respect, this study suggests that political ties could reinforce, not reduce, the negative effects of administrative voids on foreign firms.

Second, this study contributes to the nonmarket strategy literature by accounting for the often overlooked role of PA functions in international firms. It shows that PA functions reduce the intensity of political ties, suggesting that these functions and political ties could be substitutes (cf., Schuler 1996). Whereas it is conventional to expect formal PA departments to provide support for political tie development by making managers visible to the polity (cf. Post et al. 1982; Martin 1995; Doh et al. 2014), the findings of our study suggest that PA functions might support other types of nonmarket activities. At the same time, we find that the interactions between PA functions and institutional constraints can greatly vary depending on the type of constraint. PA functions may facilitate a comprehensive assessment of the effects of control constraints, thus boosting firms' incentive to develop strong political tiesin marked contrast to their impact on administrative constraints. These findings open up new dimensions for theorizing nonmarket strategy, contributing to recent scholarship that points to the importance of the links between formal organizational structures and informal social ties (Dieleman and Boddewyn 2012; Barron et al. 2017) as well as the substitution effects between different forms of nonmarket activities (Lin et al. 2015; Zhang et al. 2016). In sum, this study contributes to an insightful understanding of the determinants of CPA in emerging countries by highlighting the differential direct and moderated effects of PA functions on political ties.

Finally, this study forays into an empirical blind spot, and thus makes a contextual contribution to both CPA and international business literatures. There is limited management, strategy and international business research on Africa (Chang et al. 2010; Mellahi and Mol 2015). This does not only limit knowledge and understanding of the effects of real-life phenomena on the management and performance of firms in the Africa region, but it also excludes Africa from theory development (George et al. 2016). Our focus on the determinants of CPA in Ghana attempts to bring Africa into the international business picture. Our counter-intuitive findings add insights to the CPA literature.

Despite these contributions, our study has limitations. Founding conditions can have imprinting effects on firms' culture, strategy and organization (e.g., Boeker 1989a; Marquis 2003; Stinchcombe 1965). In other words, the environment within which a firm is founded can leave a lasting legacy on its operations. As institutions are a major component of the environment, they are an important source of imprinting (Marquis and Huang 2010) and research shows that institutional and parent firmlevel conditions have an influence on subsidiary political strategy (Hillman and Wan 2005; Shirodkar and Mohr 2015; Shirodkar et al. 2017; White et al. 2015). However due to data challenges, we could not account for home-country and parent-firm imprinting effects. Nonetheless, while we acknowledge these effects, we also note 
that they may decay over time (Marquis and Tilcsik 2013; Simsek et al. 2015) or become weaker in emerging countries where change is rapid (Han et al. 2014). The institutionally-voided and challenging nature of emerging countries can lead to poor subsidiary performance, which could further culminate in imprint decay (Boeker 1989b). In fact, through the process of shock-imprinting (Dieleman 2010), the difficulties experienced by foreign firms in emerging markets could result in the development of new strategic trajectories which may be different from those of the parent firm. With respect to CPA, foreign firms in emerging markets mainly deploy context-fitting political tactics (Zhang et al. 2016), even if they differ from those used in their home markets. Generally, because countries have different institutional characteristics, subsidiary political strategies are likely to differ from those of the parent firm or other subsidiaries in the MNE (Hillman and Keim 1995) due to host-country conditions (Wan and Hillman 2006). We argue that in challenging markets such as Ghana, it is the local institutional conditions-rather than imprinting effectswhich have a major influence on foreign firms' political strategy. Future research can explore in which institutional contexts imprinting effects are weaker or stronger.

Survey-based studies are potentially prone to measurement errors and related endogeneity effects. Additionally, this is a single-country study; hence caution should be exercised when generalizing the findings. These limitations also open up avenues for future research. First, we encourage nonmarket strategy researchers to use larger samples to explore the connections between PA functions, political ties and other political strategies. This line of research will help to ascertain whether PA functions are complements or substitutes for CPA. We also encourage future studies to explore why foreign firms in weak administrative environments are less likely to have strong political ties. In this respect, it will be useful for researchers to not only investigate inter alia whether politicians demand more bribes than bureaucrats, but to also compare the effect of administrative constraints on political tie intensity versus bureaucratic tie intensity. It would also be insightful for future research to explore the role of managerial personal imperatives and characteristics on political tie development. Further, future studies could explore the conditions under which PA functions replace political ties or moderate other variables to strengthen political ties. Despite these limitations, our study enhances our understanding of how institutional conditions affect the political behaviour of foreign firms in Sub-Saharan Africa, and sheds light on the interesting intersection between CPA, organizational structure and international business.

Open Access This article is distributed under the terms of the Creative Commons Attribution 4.0 International License (http://creativecommons.org/licenses/by/4.0/), which permits unrestricted use, distribution, and reproduction in any medium, provided you give appropriate credit to the original author(s) and the source, provide a link to the Creative Commons license, and indicate if changes were made.

\section{References}

Acemoglu, D., Johnson, S., Robinson, J., \& Thaicharoen, Y. (2003). Institutional causes, macroeconomic symptoms: Volatility, crises and growth. Journal of Monetary Economics, 50(1), 49-123. 
Acquaah, M. (2007). Managerial social capital, strategic orientation, and organizational performance in an emerging economy. Strategic Management Journal, 28(12), 1235-1255.

Ahlstrom, D., \& Bruton, G. D. (2001). Learning from successful local private firms in china: Establishing legitimacy. Academy of Management Executive, 15(4), 72-83.

Aiken, L. S., \& West, S. G. (1991). Multiple regression: Testing and interpreting interactions. London: Newbury Park.

Amoako-Gyampah, K., \& Boye, S. S. (2001). Operations strategy in an emerging economy: The case of the Ghanaian manufacturing industry. Journal of Operations Management, 19(1), 59-79.

Armstrong, J. S., \& Overton, T. S. (1977). Estimating nonresponse bias in mail surveys. Journal of Marketing Research, 14(3), 396-402.

Asiedu, E., \& Lien, D. (2004). Capital controls and foreign direct investment. World Development, 32(3), $479-490$.

Bah, E., \& Fang, L. (2015). Impact of the business environment on output and productivity in Africa. Journal of Development Economics, 114, 159-171.

Baron, D. P. (1995). The nonmarket strategy system. Sloan Management Review, 37(1), 73-85.

Barron, A., Pereda, A., \& Stacey, S. (2017). Exploring the performance of government affairs subsidiaries: A study of organisation design and the social capital of European government affairs managers at Toyota Motor Europe and Hyundai Motor Company in Brussels. Journal of World Business, 52(2), 184-196.

Batta, G., Weidenmier, M., \& Sucre Heredia, R. (2014). Political connections and accounting quality under high expropriation risk. European Accounting Review, 23(4), 485-517.

Bitzenis, A., Nushkova, V., \& Vlachos, V. A. (2012). Foreign direct investment in the FYR Macedonia: A study of motives, incentives and barriers. In A. Bitzenis, V. A. Vlachos, \& P. Papadimitriou (Eds.), Mergers and acquisitions as the pillar of foreign direct investment (pp. 209-231). Basingstoke: Palgrave Macmillan.

Blumentritt, T. P. (2003). Foreign subsidiaries' government affairs activities: The influence of managers and resources. Business and Society, 42(2), 202-233.

Boddewyn, J. J. (1988). Political aspects of MNE theory. Journal of International Business Studies, 19(3), 341-363.

Boddewyn, J. J., \& Brewer, T. L. (1994). International-business political behavior: New theoretical directions. Academy of Management Review, 19(1), 119-143.

Boeker, W. (1989a). The development and institutionalization of subunit power in organizations. Administrative Science Quarterly, 34(3), 388-410.

Boeker, W. (1989b). Strategic change: The effects of founding and history. Academy of Management Journal, 32(3), 489-515.

Boso, N., Story, V. M., \& Cadogan, J. W. (2013). Entrepreneurial orientation, market orientation, network ties, and performance: Study of entrepreneurial firms in a developing economy. Journal of Business Venturing, 28(6), 708-727.

Bowerman, B. L., \& O’Connell, R. T. (1990). Linear statistical models: An applied approach (2nd ed.). Belmont: Duxbury.

Brammer, S., \& Millington, A. (2006). Firm size, organizational visibility and corporate philanthropy: An empirical analysis. Business Ethics: A European Review, 15(1), 6-18.

Brockman, P., Rui, O. M., \& Zou, H. (2013). Institutions and the performance of politically connected M\&As. Journal of International Business Studies, 44(8), 833-852.

Chan, C. M., \& Makino, S. (2007). Legitimacy and multi-level institutional environments: Implications for foreign subsidiary ownership structure. Journal of International Business Studies, 38(4), $621-638$.

Chang, S. J., Witteloostuijn, A., \& Eden, L. (2010). From the editors: Common method variance in international business research. Journal of International Business Studies, 41(2), 178-184.

Chen, Y., Shen, C., \& Lin, C. (2014). The benefits of political connection: Evidence from individual bank-loan contracts. Journal of Financial Services Research, 45(3), 287-305.

Chiu, S., \& Sharfman, M. (2011). Legitimacy, visibility, and the antecedents of corporate social performance: An investigation of the instrumental perspective. Journal of Management, 37(6), $1558-1585$.

Claessens, S., Feijen, E., \& Laeven, L. (2008). Political connections and preferential access to finance: The role of campaign contributions. Journal of Financial Economics, 88(3), 554-580.

Cohen, J., Cohen, P., West, S. G., \& Aiken, L. S. (2003). Applied multiple regression/correlation analysis for the behavioral sciences. Mahwah: Lawrence Erlbaum Associates. 
Cook, R. D., \& Weisberg, S. (1982). Residuals and influence in regression. New York: Chapman and Hall.

Cuervo-Cazurra, A. (2016). Corruption in international business. Journal of World Business, 51(1), 35-49.

Danis, W. M., Chiaburu, D. S., \& Lyles, M. A. (2010). The impact of managerial networking intensity and market-based strategies on firm growth during institutional upheaval: A study of small and medium-sized enterprises in a transition economy. Journal of International Business Studies, 41(2), 287-307.

Darendeli, I. S., \& Hill, T. L. (2016). Uncovering the complex relationships between political risk and MNE firm legitimacy: Insights from Libya. Journal of International Business Studies, 47(1), 68-92.

Darnall, N., Henriques, I., \& Sadorsky, P. (2010). Adopting proactive environmental strategy: The influence of stakeholders and firm size. Journal of Management Studies, 47(6), 1072-1094.

Decker, S. (2011). Corporate political activity in less developed countries: The Volta River project in Ghana, 1958-66. Business History, 53(7), 993-1017.

Desai, M. A., Foley, C. F., \& Hines, J. R., Jr. (2006). Capital controls, liberalizations, and foreign direct investment. Review of Financial Studies, 19(4), 1433-1464.

Desai, R. M., \& Olofsgard, A. (2011). The costs of political influence: Firm-level evidence from developing countries. Quarterly Journal of Political Science, 6(2), 137-178.

Dieleman, M. (2010). Shock-imprinting: External shocks and ethnic Chinese business groups in Indonesia. Asia Pacific Journal of Management, 27(3), 481-502.

Dieleman, M., \& Boddewyn, J. J. (2012). Using organization structure to buffer political ties in emerging markets: A case study. Organization Studies, 33(1), 71-95.

Doh, J., Lawton, T., Rajwani, T., \& Paroutis, S. (2014). Why your company may need a chief external officer: Upgrading external affairs can help align strategy and improve competitive advantage. Organization Dynamics, 43(2), 96-104.

Dooley, M. P., \& Isard, P. (1980). Capital controls, political risk, and deviations from interest-rate parity. Journal of Political Economy, 88(2), 370-384.

Durbin, J., \& Watson, G. S. (1951). Testing for serial correlation in least squares regression. II. Biometrika, 38(1), 159-178.

Essel, I. (2015). Create, loot and share agenda confirmed in shocking exposé on Woyome scandal. http:// www.myjoyonline.com/news/2015/july-11th/create-loot-and-share-agenda-confirmed-in-shockingexpos-on-woyome-scandal.php. Accessed 20 Apr 2017.

Faruq, H., Webb, M., \& Yi, D. (2013). Corruption, bureaucracy and firm productivity in Africa. Review of Development Economics, 17(1), 117-129.

Field, A. (2013). Discovering statistics using SPSS (4th ed.). London: Sage Publications.

Fisman, R., \& Svensson, J. (2007). Are corruption and taxation really harmful to growth? Firm level evidence. Journal of Development Economics, 83(1), 63-75.

Fornell, C., \& Larcker, D. F. (1981). Evaluating structural equation models with unobservable variables and measurement error. Journal of Marketing Research, 18(1), 39-50.

Frynas, J. G., Mellahi, K., \& Pigman, G. A. (2006). First mover advantages in international business and firm-specific political resources. Strategic Management Journal, 27(4), 321-345.

Frynas, J. G., \& Stephens, S. (2015). Political corporate social responsibility: Reviewing theories and setting new agendas. International Journal of Management Reviews, 17(4), 483-509.

Fuller, J. B., Hester, K., Barnett, T., Frey, L., Relyea, C., \& Beu, D. (2006). Perceived external prestige and internal respect: New insights into the organizational identification process. Human Relations, $59(6), 815-846$.

García-Canal, E., \& Guillén, M. F. (2008). Risk and the strategy of foreign location choice in regulated industries. Strategic Management Journal, 29(10), 1097-1115.

George, G., Corbishley, C., Khayesi, J. N. O., Haas, M. R., \& Tihanyi, L. (2016). Bringing Africa in: Promising directions for management research. Academy of Management Journal, 59(2), 377-393.

Grabel, I. (2016). Capital controls in a time of crisis. In P. Arestis \& M. Sawyer (Eds.), Financial liberalisation: Past, present and future (1st ed., pp. 177-223). Basingstoke: Palgrave Macmillan.

Gray, V., \& Lowery, D. (1997). Reconceptualizing pac formation: It's not a collective action problem, and it may be an arms race. American Politics Quarterly, 25(3), 319-346.

Greening, D. W., \& Gray, B. (1994). Testing a model of organizational response to social and political issues. Academy of Management Journal, 37(3), 467-498. 
Grier, K. B., Munger, M. C., \& Roberts, B. E. (1994). The determinants of industry political activity, 1978-1986. American Political Science Review, 88(4), 911-926.

Griffin, J. J., \& Dunn, P. (2004). Corporate public affairs: Commitment, resources, and structure. Business and Society, 43(2), 196-220.

Guo, H., Xu, E. M., \& Jacobs, M. (2014). Managerial political ties and firm performance during institutional transitions: An analysis of mediating mechanisms. Journal of Business Research, 67(2), 116-127.

Hadani, M., \& Schuler, D. A. (2013). In search of El Dorado: The elusive financial returns on corporate political investments. Strategic Management Journal, 34(2), 165-181.

Hair, J. F., Anderson, R. E., Tatham, R. L., \& Black, W. C. (1998). Multivariate data analysis (5th ed.). Delhi: Pearson Education.

Han, Y., Zheng, E., \& Xu, M. (2014). The influence from the past: Organizational imprinting and firms' compliance with social insurance policies in china. Journal of Business Ethics, 122(1), 65-77.

Hansen, W. L., \& Mitchell, N. J. (2000). Disaggregating and explaining corporate political activity: Domestic and foreign corporations in national politics. American Political Science Review, 94(4), 891-903.

Hardy, M. A. (1993). Regression with dummy variables (quantitative applications in the social sciences). Newbury Park: Sage Publications.

Heidenreich, S., Mohr, A., \& Puck, J. (2015). Political strategies, entrepreneurial overconfidence and foreign direct investment in developing countries. Journal of World Business, 50(4), 793-803.

Henisz, W. J., \& Zelner, B. A. (2003). The strategic organization of political risks and opportunities. Strategic Organization, 1(4), 451-460.

Hillman, A. J. (2003). Determinants of political strategies in US Multinationals. Business and Society, 42(4), 455-484.

Hillman, A. J., \& Hitt, M. A. (1999). Corporate political strategy formulation: A model of approach, participation, and strategy decisions. Academy of Management Review, 24(4), 825-842.

Hillman, A., \& Keim, G. (1995). International variation in the business-government interface: Institutional and organizational considerations. Academy of Management Review, 20(1), 193-214.

Hillman, A. J., Keim, G. D., \& Schuler, D. (2004). Corporate political activity: A review and research agenda. Journal of Management, 30(6), 837-857.

Hillman, A. J., \& Wan, W. P. (2005). The determinants of MNE subsidiaries' political strategies: Evidence of institutional duality. Journal of International Business Studies, 36(3), 322-340.

Hillman, A. J., Zardkoohi, A., \& Bierman, L. (1999). Corporate political strategies and firm performance: Indications of firm specific benefits from personal service in the US government. Strategic Management Journal, 20, 67-81.

Hinkin, T. R. (1995). A review of scale development practices in the study of organizations. Journal of Management, 21(5), 967-988.

Holburn, G. L. F., \& Zelner, B. A. (2010). Political capabilities, policy risk, and international investment strategy: Evidence from the global electric power generation industry. Strategic Management Journal, 31(12), 1290-1315.

Houston, J. F., Jiang, L., Lin, C., \& Ma, Y. (2014). Political connections and the cost of bank loans. Journal of Accounting Research, 52(1), 193-243.

Jia, M., \& Zhang, Z. (2015). News visibility and corporate philanthropic response: Evidence from privately owned Chinese firms following the Wenchuan earthquake. Journal of Business Ethics, 129(1), 93-114.

Johnson, S., \& Mitton, T. (2003). Cronyism and capital controls: Evidence from Malaysia. Journal of Financial Economics, 67(2), 351-382.

Keim, G., \& Baysinger, B. (1988). The efficacy of business political activity: Competitive considerations in a principal-agent context. Journal of Management, 14(2), 163-180.

Khanna, T., Palepu, K. G., \& Sinha, J. (2005). Strategies that fit emerging markets. Harvard Business Review, 83(6), 63-76.

Khwaja, A. I., \& Mian, A. (2005). Do lenders favor politically connected firms? Rent provision in an emerging financial market. Quarterly Journal of Economics, 120(4), 1371-1411.

Kim, E.-H., \& Lyon, T. P. (2011). Strategic environmental disclosure: Evidence from the DOE's voluntary green-house gas registry. Journal of Environmental Economics and Management, 61(3), 311-326. 
Kingsley, A. F., Vanden Bergh, R. G., \& Bonardi, J. P. (2012). Political markets and regulatory uncertainty: Insights and implications for integrated strategy. Academy of Management Perspectives, 26(3), 52-67.

Klingebiel, R., \& Stadler, C. (2015). Opportunities and challenges for empirical research in Africa. Africa Journal of Management, 1(2), 194-200.

Kobrin, S. J. (1982). Managing political risk assessment. Berkeley: University of California Press.

Kostka, G., \& Zhou, J. (2013). Government-business alliances in state capitalist economies: Evidence from low-income markets in china. Business and Politics, 15(2), 245-274.

Kostova, T., \& Zaheer, S. (1999). Organizational legitimacy under conditions of complexity: The case of the multinational enterprise. Academy of Management Review, 24(1), 64-81.

Lawton, T. C., Doh, J. P., \& Rajwani, T. (2014). Aligning for advantage. Oxford: Oxford University Press.

Lawton, T., McGuire, S., \& Rajwani, T. (2013a). Corporate political activity: A literature review and research agenda. International Journal of Management Reviews, 15(1), 86-105.

Lawton, T., Rajwani, T., \& Doh, J. (2013b). The antecedents of political capabilities: A study of ownership, cross-border activity and organization at legacy airlines in a deregulatory context. International Business Review, 22(1), 228-242.

Leuz, C., \& Oberholzer-Gee, F. (2006). Political relationships, global financing, and corporate transparency: Evidence from Indonesia. Journal of Financial Economics, 81(2), 411-439.

Li, H., \& Zhang, Y. (2007). The role of managers' political networking and functional experience in new venture performance: Evidence from china's transition economy. Strategic Management Journal, 28(8), 791-804.

Liedong, T. A., \& Rajwani, T. (2017). The impact of managerial political ties on corporate governance and debt financing: Evidence from Ghana. Long Range Planning, In Press.. https://doi. org/10.1016/j.1rp.2017.06.006.

Lin, K. J., Tan, J., Zhao, L., \& Karim, K. (2015). In the name of charity: Political connections and strategic corporate social responsibility in a transition economy. Journal of Corporate Finance, $32,327-346$.

Lui, F. T. (1985). An equilibrium queuing model of bribery. Journal of Political Economy, 93(4), $760-781$.

Luiz, J., \& Stewart, C. (2014). Corruption, South African multinational enterprises and institutions in africa. Journal of Business Ethics, 124(3), 383-398.

Luo, Y. (2006). Political behavior, social responsibility, and perceived corruption: A structuration perspective. Journal of International Business Studies, 37(6), 747-766.

Lux, S., Crook, T. R., \& Woehr, D. J. (2011). Mixing business with politics: A meta-analysis of the antecedents and outcomes of corporate political activity. Journal of Management, 37(1), $223-247$.

Marquis, C. (2003). The pressure of the past: Network imprinting in intercorporate communities. Administrative Science Quarterly, 48(4), 655-689.

Marquis, C., \& Huang, Z. (2010). Acquisitions as exaptation: The legacy of founding institutions in the U.S. commercial banking industry. Academy of Management Journal, 53(6), 1441-1473.

Marquis, C., \& Tilcsik, A. (2013). Imprinting: Toward a multilevel theory. Academy of Management Annals, 7(1), 195-245.

Martin, C. J. (1995). Nature or nurture? Sources of firm preference for national health reform. American Political Science Review, 89(4), 898-913.

Mellahi, K., Frynas, J. G., Sun, P., \& Siegel, D. (2016). A review of the nonmarket strategy literature: Toward a multi-theoretical integration. Journal of Management, 42(1), 143-173.

Mellahi, K., \& Mol, M. J. (2015). Africa is just like every other place, in that it is unlike any other place. Africa Journal of Management, 1(2), 201-209.

Mesquita, L. F., \& Lazzarini, S. G. (2008). Horizontal and vertical relationships in developing economies: Implications for SMEs' access to global markets. Academy of Management Journal, 51(2), 359-380.

Meznar, M. B., \& Nigh, D. (1995). Buffer or bridge? Environmental and organizational determinants of public affairs activities in American firms. Academy of Management Journal, 38(4), 975-996.

Mitchell, N. J., Hansen, W. L., \& Jepsen, E. M. (1997). The determinants of domestic and foreign corporate political activity. The Journal of Politics, 59(4), 1096-1113.

Mondejar, R., \& Zhao, H. (2013). Antecedents to government relationship building and the institutional contingencies in a transition economy. Management International Review, 53(4), 579-605. 
Murray, J. Y., Kotabe, M., \& Joe, N. Z. (2005). Strategic alliance-based sourcing and market performance: Evidence from foreign firms operating in china. Journal of International Business Studies, 36(2), 187-208.

Murtha, T. P., \& Lenway, S. A. (1994). Country capabilities and the strategic state: How national political institutions affect multinational corporations' strategies. Strategic Management Journal, 15(S2), $113-129$.

Nee, V. (1992). Organizational dynamics of market transition: Hybrid forms, property rights, and mixed economy in china. Administrative Science Quarterly, 37(1), 1-27.

Nell, P. C., Puck, J., \& Heidenreich, S. (2015). Strictly limited choice or agency? Institutional duality, legitimacy, and subsidiaries' political strategies. Journal of World Business, 50(2), 302-311.

Nunnally, J. C. (1978). Psychometric theory. New York: McGraw-Hill.

Oliver, C., \& Holzinger, I. (2008). The effectiveness of strategic political management: A dynamic capabilities framework. The Academy of Management Review, 33(2), 496-520.

Park, S. H., \& Luo, Y. (2001). Guanxi and organizational dynamics: Organizational networking in Chinese firms. Strategic Management Journal, 22(5), 455-477.

Peng, M. W., \& Luo, Y. (2000). Managerial ties and firm performance in a transition economy: The nature of a micro-macro link. Academy of Management Journal, 43(3), 486-501.

Podsakoff, P. M., MacKenzie, S. B., Jeong-Yeon, L., \& Podsakoff, N. P. (2003). Common method biases in behavioral research: A critical review of the literature and recommended remedies. Journal of Applied Psychology, 88(5), 879-903.

Post, J. E., Murray, E. A., \& Dickie, R. B. (1982). The public affairs function in American corporations: Development and relations with corporate planning. Long Range Planning, 15(2), 12-21.

Puck, J. F., Rogers, H., \& Mohr, A. T. (2013). Flying under the radar: Foreign firm visibility and the efficacy of political strategies in emerging economies. International Business Review, 22(6), 1021-1033.

Puffer, S. M., McCarthy, D. J., \& Boisot, M. (2010). Entrepreneurship in Russia and China: The impact of formal institutional voids. Entrepreneurship: Theory and Practice, 34(3), 441-467.

Rajan, R. G., \& Zingales, L. (2003). The great reversals: The politics of financial development in the twentieth century. Journal of Financial Economics, 69(1), 5-50.

Rajwani, T., \& Liedong, T. A. (2015). Political activity and firm performance within nonmarket research: A review and international comparative assessment. Journal of World Business, 50(2), 273-283.

Rodriguez, P., Uhlenbruck, K., \& Eden, L. (2005). Government corruption and the entry strategies of multinationals. Academy of Management Review, 30(2), 383-396.

Saiia, D. H., Carroll, A. B., \& Buchholtz, A. K. (2003). Philanthropy as strategy. Business and Society, 42(2), 169-201.

Scherer, A. G., \& Palazzo, G. (2007). Toward a political conception of corporate responsibility: Business and society seen from a Habermasian perspective. Academy of Management Review, 32(4), 1096-1120.

Scherer, A. G., \& Palazzo, G. (2011). The new political role of business in a globalized world: A review of a new perspective on CSR and its implications for the firm, governance, and democracy. Journal of Management Studies, 48(4), 899-931.

Schuler, D. A. (1996). Corporate political strategy and foreign competition: The case of the steel industry. Academy of Management Journal, 39(3), 720-737.

Schuler, D. A., Rehbein, K., \& Cramer, R. D. (2002a). Pursuing strategic advantage through political means: A multivariate approach. Academy of Management Journal, 45(4), 659-672.

Schuler, D. A., Schnietz, K. E., \& Baggett, L. S. (2002b). Determinants of foreign trade mission participation: An analysis of corporate political and trade activities. Business and Society, 41(1), 6-35.

Schwab, K. (2016). The global competitiveness report 2016-2017. Geneva: World Economic Forum.

Sheng, S., Zhou, K. Z., \& Li, J. J. (2011). The effects of business and political ties on firm performance: Evidence from China. Journal of Marketing, 75(1), 1-15.

Shirodkar, V., Konara, P., \& McGuire, S. (2017). Home institutional imprinting, R\&D intensity and lobbying expenditure of foreign firms in the U.S. British Journal of Management, 28(4), 589-608.

Shirodkar, V., \& Mohr, A. (2015). Resource tangibility and foreign firms' corporate political strategies in emerging economies: Evidence from India. Management International Review, 55, 801-825.

Siegel, J. (2007). Contingent political capital and international alliances: Evidence from South Korea. Administrative Science Quarterly, 52(4), 621-666.

Simsek, Z., Fox, B. C., \& Heavey, C. (2015). "What's past is prologue": A framework, review, and future directions for organizational research on imprinting. Journal of Management, 41(1), 288-317. 
Spencer, J., \& Gomez, C. (2011). MNEs and corruption: The impact of national institutions and subsidiary strategy. Strategic Management Journal, 32(3), 280-300.

Stinchcombe, A. L. (1965). Social structure and organizations. In J. G. March (Ed.), Handbook of organizations (pp. 142-193). Chicago: Rand McNally.

Suchman, M. C. (1995). Managing legitimacy: Strategic and institutional approaches. Academy of Management Review, 20(3), 571-610.

Sun, P., Mellahi, K., \& Thun, E. (2010). The dynamic value of MNE political embeddedness: The case of the Chinese automobile industry. Journal of International Business Studies, 41(7), 1161-1182.

Svensson, J. (2005). Eight questions about corruption. Journal of Economic Perspectives, 19(3), 19-42.

Tyler, T., Degoey, P., \& Smith, H. (1996). Understanding why the justice of group procedures matters: A test of the psychological dynamics of the group-value model. Journal of Personality and Social Psychology, 70(5), 913-930.

Udayasankar, K. (2008). Corporate social responsibility and firm size. Journal of Business Ethics, 83(2), $167-175$.

van den Bersselaar, D., \& Decker, S. (2011). 'No longer at ease': Corruption as an institution in West Africa. International Journal of Public Administration, 34(11), 741-752.

Wan, W. P., \& Hillman, A. J. (2006). One of these things is not like the others: What contributes to dissimilarity among MNE subsidiaries' political strategy? Management International Review, 46(1), $85-107$.

Wei, S. (2000). How taxing is corruption on international investors? Review of Economics and Statistics, $82(1), 1-11$.

Weidenbaum, M. L. (1980). Public policy: No longer a spectator sport for business. Journal of Business Strategy, 1(1), 46-53.

White, G. O., Boddewyn, J. J., \& Galang, R. M. N. (2015). Legal system contingencies as determinants of political tie intensity by wholly owned foreign subsidiaries: Insights from the Philippines. Journal of World Business, 50(2), 342-356.

Wiklund, J., \& Shepherd, D. (2005). Entrepreneurial orientation and small business performance: A configurational approach. Journal of Business Venturing, 20(1), 71-91.

Winkler, J. D., Kanouse, D. E., \& Ware, J. E. (1982). Controlling for acquiescence response set in scale development. Journal of Applied Psychology, 67(5), 555-561.

Wocke, A., \& Moodley, T. (2015). Corporate political strategy and liability of foreignness: Similarities and differences between local and foreign firms in the South African health sector. International Business Review, 24(4), 700-709.

World Bank. (2013). Enterprise surveys. http://www.enterprisesurveys.org. Accessed 5 May 2014.

World Bank. (2017). Doing Business 2017: Equal opportunity for all. Washington: World Bank.

Xin, K. K., \& Pearce, J. L. (1996). Guanxi: Connections as substitutes for formal institutional support. Academy of Management Journal, 39(6), 1641-1658.

Yeboah, I. (2013). It's time to stop the create, loot and share syndrome. http://www.graphic.com.gh/news/ politics/it-s-time-to-stop-the-create-loot-and-share-syndrome-martin-amidu.html. Accessed $20 \mathrm{Apr}$ 2017.

Yiu, D. W., Lau, C. M., \& Bruton, G. D. (2007). International venturing by emerging economy firms: The effects of firm capabilities, home country networks, and corporate entrepreneurship. Journal of International Business Studies, 38(4), 519-540.

Yiu, D., \& Makino, S. (2002). The choice between joint venture and wholly owned subsidiary: An institutional perspective. Organization Science, 13(6), 667-683.

Yu, J., Lo, C. W., \& Li, P. H. Y. (2017). Organizational visibility, stakeholder environmental pressure and corporate environmental responsiveness in china. Business Strategy and the Environment, 26(3), $371-384$.

Zaheer, S., \& Zaheer, A. (1997). Country effects on information seeking in global electronic networks. Journal of International Business Studies, 28(1), 77-100.

Zhang, J., Marquis, C., \& Qiao, K. (2016). Do political connections buffer firms from or bind firms to the government? A study of corporate charitable donations of Chinese firms. Organization Science, 27(5), 1307-1324.

Zheng, Q., Luo, Y., \& Maksimov, V. (2015). Achieving legitimacy through corporate social responsibility: The case of emerging economy firms. Journal of World Business, 50(3), 389-403. 